O. G. Vagonova, Dr. Sc. (Econ.), Prof., orcid.org/0000-0001-6553-7771, D. V.Arzhevichev, orcid.org/0000-0002-1083-3917, O. M. Cherkashchenko, orcid.org/0000-0002-8430-9923
National Mining University, Dnipro, Ukraine, e-mail: vagonovaag@gmail.com

\title{
ECONOMIC RATIONALE FOR A STRATEGY OF FURTHER URANIUM PRODUCTION WASTE MANAGEMENT
}

\author{
О. Г. Вагонова, д-р екон. наук, проф., \\ orcid.org/0000-0001-6553-7771, \\ Д. В.Аржевічев, \\ orcid.org/0000-0002-1083-3917, \\ О. М. Черкащенко, \\ orcid.org/0000-0002-8430-9923
}

\author{
Державний вищий навчальний заклад „Національний \\ гірничий університет“, м. Дніпро, Україна, е-mail \\ vagonovaag@gmail.com
}

\section{ЕКОНОМІЧНЕ ОБГРУНТУВАННЯ СТРАТЕГІЇ ПОДАЛЬШОГО ПОВОДЖЕННЯ З ВІДХОДАМИ УРАНОВОГО ВИРОБНИЦТВА}

Purpose. Scientific substantiation of strategy of further uranium production waste management of the "Prydniprovskyi Chemical Plant" Production Association ("PCP" PA) and directions of possible use of waste storage areas in the future.

Methodology. The results were obtained through the following methods: critical analysis and systematization while estimating the impact of uranium production wastes on the population and territory; statistical and economic analysis while studying socio-economic and ecological consequences of uranium production waste disposal on urban lands; mathematical modelling in economics and optimization while substantiating directions of further management of uranium production wastes.

Findings. Influence of different factors on choosing a strategy of further management of uranium production wastes of the "PCP" PA is evaluated. Considering the requirement for long-term maintenance of conformity of radioactive waste (RAW) storages state with laws and regulations in force and minimization of expenses on servicing them, a strategy of further management of uranium production wastes of the "PCP" PA has been developed. The strategy focuses on taking a number of remediation measures on contaminated territories which allow putting them out of service and regulatory control and getting these territories round to free, unrestricted or at least beneficial use by local communities or new owners. A business mechanism of implementing the strategy of further treating of uranium production wastes of the "PCP" PA is suggested. It includes preparation, selection, design, technology and substantiated trends of possible use of the lands in the future, which are directed at minimizing costs on servicing the storages.

Originality. New conceptual approaches to the strategy of further management of uranium production wastes of the "PCP" PA have been suggested and the business mechanism of implementing the chosen strategy has been improved.

Practical value. A process algorithm for putting storage areas out of regulatory control is developed and the procedure of planning and taking measures on remediation is justified according to the optimization principle. The most appropriate ways of using the storage areas of uranium production wastes of the "PCP" PA after their remediation are proposed.

Keywords: economic rationale, strategy, area contamination, wastes, uranium production

Introduction. Among a great number of various wastes which pollute the environment, condition accumulation of harmful substances in it and create a hazard to people's health and lives, uranium production wastes hold a special place, first of all those which have been stored without ecological and economic substantiation on urban lands immediately near the spots of uranium ore dressing and processing.

On the territory of Kamianske and surrounding areas of the Dnipropetrovsk region there are tailings facilities of the "PCP" PA at which during the period between

(C) Vagonova O. G., Arzhevichev D. V., Cherkashchenko O. M., 2018
1948 and 1991 industrial processing of uranium ores and other uranium-bearing raw materials was conducted. All in all on the territory concerned 9 tailings facilities of products of processing uranium ores were created which have accumulated about 42 million tons of wastes with general activity being $31.8 \cdot 10^{14} \mathrm{~Bq}$.

Nowadays, radioactive waste storages remain the source of considerable threat to workers of the enterprises situated on the territory of the "PCP" PA and residents on their border territory, which conditions the necessity for protecting and monitoring the state of storages as well as periodic performance of work aimed at maintaining their secure state. All these result in consid- 
erable expenses on premises security, monitoring system, and renovation work. Taking into account the fact that available waste activity does not actually decrease over thousands of years, the issue of further management of uranium production wastes of the "PCP" PA requires urgent solution.

Analysis of the recent research and publications. The situation which currently occurs at the RAW storages is significantly conditioned by the lack of a clear scientifically grounded strategy of further management of uranium production wastes of the "PCP" PA [1]. The world experience and available examples of the most successful solution of the similar problems [2] show that success is achieved only when all the groups of objective and subjective factors which influence making a final decision are considered while choosing such a strategy; namely, they include social, biomedical, ecological and economic ones (Fig. 1).

The main principle while choosing the strategy of further management of uranium production wastes and making decisions regarding certain remediation measures involves expecting more benefits of their introduction than harm [3]. According to the optimization principle, it is necessary to find the most appropriate form of remediation among all the possible ones, including the thermal waste distraction [4].

Previously, while choosing a strategy of radiological protection a number of European countries tried to apply approaches which were based on comparing the cost of remediation measures with the money equivalent of risk which involved assessing losses from public exposure according to the conditional number of deadly repercussions caused by radiation as long as no measures were taken [5]. By reference to this, appropriate level of measure costs was defined to decrease averted dose. At the same time, the risk of emergence of long-term effects (cancer diseases) was taken at the level of 0.05 cases/Sv, while life expectancy with cancer was taken to be 15 years [5].

However, in most cases this approach did not work and it was impossible to substantiate the necessity of taking expensive remediation measures only based on radiological data. Largely, social and political components rather than radiological expediency were critical while choosing the measures. At that, the decision was made regardless of radiation pollution data, but based on ideas of social security or developing comfortable conditions of living in the polluted environment [5]. Thus, apart from objective factors, the subjective ones are to be considered while choosing remedial measures, namely, social factors, legislative requirements, experience of performing similar actions in other countries.

To consider different arguments when making decisions and choosing certain strategies methodology of multi-attributive analyses (MAA) was suggested [6]. This methodology allows considering both objective and subjective components: determinants of health, economic and social factors and others.

It is worth mentioning that while applying the approaches considered, the eventual result is often ambiguous and depends on the person conducting the analyses and his/her interest in getting certain analysis results. Moreover, their application does not always take into account peculiarities of available radioactive waste storages.

Objectives of the article. The article aims at scientific substantiation of the strategy of further management of uranium production wastes of the "PCP" PA.

Presentation of the main research. Each storage of radioactive wastes (RAW) is a unique object. The storages differ from each other in their sizes, the amount of accumulated waste, type and level of taken remediation measures, radiative properties, availability and type of objects on the border territory, land topography and others. Considering these factors, there can be no universal solutions concerning the management of uranium production wastes at a particular storage and no common decisions on choosing remediation measures. However, regardless of differences of the storages there is a general problem which is to minimize the expenses and losses related to all the storages, both nowadays and in the future, along with main-

\begin{tabular}{|c|c|c|c|}
\hline & \multicolumn{2}{|c|}{$\begin{array}{c}\text { STRATEGY } \\
\text { of management of uranium production } \\
\text { wastes of the "PCP" PA }\end{array}$} & \\
\hline $\begin{array}{l}\text { Social factors: } \\
\text { 1. Concerns about: } \\
\text { the future } \\
\text { 2. Distrust in the } \\
\text { government } \\
\text { authorities' } \\
\text { activities } \\
\text { 3. Attempts to } \\
\text { follow examples } \\
\text { of others }\end{array}$ & $\begin{array}{l}\text { Medical and } \\
\text { biological facrors: } \\
\text { 1. Radiation dose for the } \\
\text { population } \\
\text { 2. Radiation dose for the } \\
\text { workers } \\
\text { 3. Risks of long-term } \\
\text { effects of radiation } \\
\text { 4. Risks of genetic } \\
\text { effects of radiation } \\
\text { 5. Risks of mutation } \\
\text { occurrence }\end{array}$ & $\begin{array}{l}\text { Economic factors: } \\
\text { 1. Expenditures for } \\
\text { protection and monitoring } \\
\text { 2. Expenses on bringing } \\
\text { the storages into secure } \\
\text { state } \\
\text { 3. Expenses on decreasing } \\
\text { harmful influence of the } \\
\text { storages on the population } \\
\text { and environment } \\
\text { 4. Expenses on social } \\
\text { activities } \\
\text { 5. Expenses on disposing } \\
\text { uranium production } \\
\text { wastes }\end{array}$ & $\begin{array}{l}\text { Ecological factors: } \\
\text { 1. Land pollution by } \\
\text { wastes } \\
\text { 2. Air and underground } \\
\text { water pollution } \\
\text { 3. Putting the areas out } \\
\text { beneficial use } \\
\text { 4. Restriction of } \\
\text { possible applications }\end{array}$ \\
\hline
\end{tabular}

Fig. 1. Scheme of influence of different factors on choosing the strategy of further management of uranium production wastes of the "PCP" $P A$ 
taining the acceptable safety level for the population and workers. As a formula, this task involves minimization of composite function which is a sum of current and future expenses along with restrictions conditioned by the necessity to meet the safety requirements

$$
F=\sum E_{c}+\sum E_{f}^{c o n}+\sum L_{c}+\sum L_{f}^{c o n} \rightarrow \min ,
$$

where $\sum E_{c}, \sum E_{f}^{c o n}$ are the sum of the current and future expenses, correspondingly, converted to the present moment; $\sum L c, \sum L_{f}^{c o n}$ are the sum of the current and future losses, accordingly, converted to the present moment.

The restrictions conditioned by the necessity to meet the safety requirements can be presented as

$$
D_{\text {d.ann }}^{\text {pop }} \leq 1 m S v \quad \text { and } \quad D_{d . a n n}^{\text {wor }} \leq 20 m S v
$$

where $D_{\text {d.ann }}^{\text {pop }}$ and $D_{\text {d.ann }}^{\text {wor }}$ are, correspondingly, dose equivalents of the population and workers, complementary to the natural one, as a result of RAW storage impact.

The analysis of the economic results of disposal of uranium production wastes of the "PCP" PA conducted by us showed that among different groups of the expenses and losses conditioned by this disposal, the most significant ones have been the expenditures for measures of protecting and monitoring the state of the RAW storages as well as measures directed at bringing the storages into secure state and decreasing their harmful influence on the environment. Taking this into account, the composite function can be written in the following way

$$
F=E_{c}^{p m}+E_{f}^{p m}+E_{c}^{r m}+E_{f}^{r m} \rightarrow \min ,
$$

where $E_{c}^{p m}, E_{f}^{p m}$ are, correspondingly, the current expenses and the future ones converted to the present moment on measures protecting and monitoring the state of the RAW storages; $E_{c}^{r m}, B_{f}^{r m}$ are, correspondingly, the current expenses and the future ones converted to the present moment on remediation measures, i.e. measures aimed at bringing the storages into secure state and decreasing their harmful influence on the environment.

The experience of many countries regarding the remediation measures shows that with the appropriate strategy it was possible to reduce the future expenses on servicing and monitoring the storage to zero and to minimize those on remedial measures. Available modern technologies of implementing engineering and geotechnical measures on the contaminated areas allow developing safe conditions there for a very long term in immediate proximity to the unlimited natural resource management. Due to the requirement for stable and longterm state of the storages by the legislation and regulatory enactments of a number of countries across the world, requirements for protective barriers (ground coatings of the storages, availability of impervious screens, protection dikes, hydraulic structure characteristics and others) have been established. They are to provide reliable protection of the storages for no less than 200 years [6].

Taking into account the foregoing, the strategy of further management of uranium production wastes of the
"PCP" PA is to involve implementing a range of measures of remediation on contaminated and polluted lands which allow putting them out of servicing and regulatory control and getting these territories round to free, unrestricted or at least beneficial use by local communities or new owners.

While storing radioactive wastes or tails of uranium production, certain risks of unrestricted use of these territories can remain after completing remediation measures. Under these conditions restrictions can be introduced regarding the use and treatment of the land. For example, the tails are to be fenced along with the relevant danger symbols. On the surface of the tails there can be located only those objects and performed only those works which are allowed by the project and are safe regarding the coating and protection dikes being maintained in the relevant state.

As a rule, it is forbidden for a long time (hundreds of years) to conduct earthwork operations which can result in loss of ground coating integrity on the storage site; construction of residential buildings, wells for drinking or agricultural purposes is also forbidden. Certain requirements for plant cover and drainage are imposed. Unauthorized access of people to certain areas can be prohibited. In most cases people who are responsible for meeting the safety requirements while using these areas are either local self-government authorities or owners, who can use this land under certain conditions and at the same time are responsible for nature management safety.

The business mechanism of implementing the strategy of further management of uranium production wastes of the "PCP" PA is given in Fig. 2. It includes the following 5 stages:

- the first stage is preparatory;

- the second stage - selective;

- the third stage - designing;

- the fourth stage - technological;

- the fifth stage - monitoring.

At the first stage the radiation situation at the RAW storages is estimated (gamma emission rate, equivalent equilibrium volumetric activity, radon exhalation, state of the coating, state of protection dikes and others), sources and possible volumes of funding of remediation are defined, the active legislation and regulations regarding possible use of storage areas after completing remedial measures are analysed.

At the second stage based on the data of the analyses of the storage state and possible volumes of funding remediation measures, a particular storage (or storages) for implementation of the defined strategy is chosen and directions of remedial works are determined. A very important aspect for choosing rehabilitative measures includes making a decision as for defining possible potential users of the storage sites after taking remediation actions and decisions agreement on further use of the territories and objects. Beneficial use of these objects or territories after securing them is the most efficient. The position of the parties concerned is critical while implementing the strategy at this stage.

A the third, designing, stage the project of remediation performance is developed and approved and, if re- 


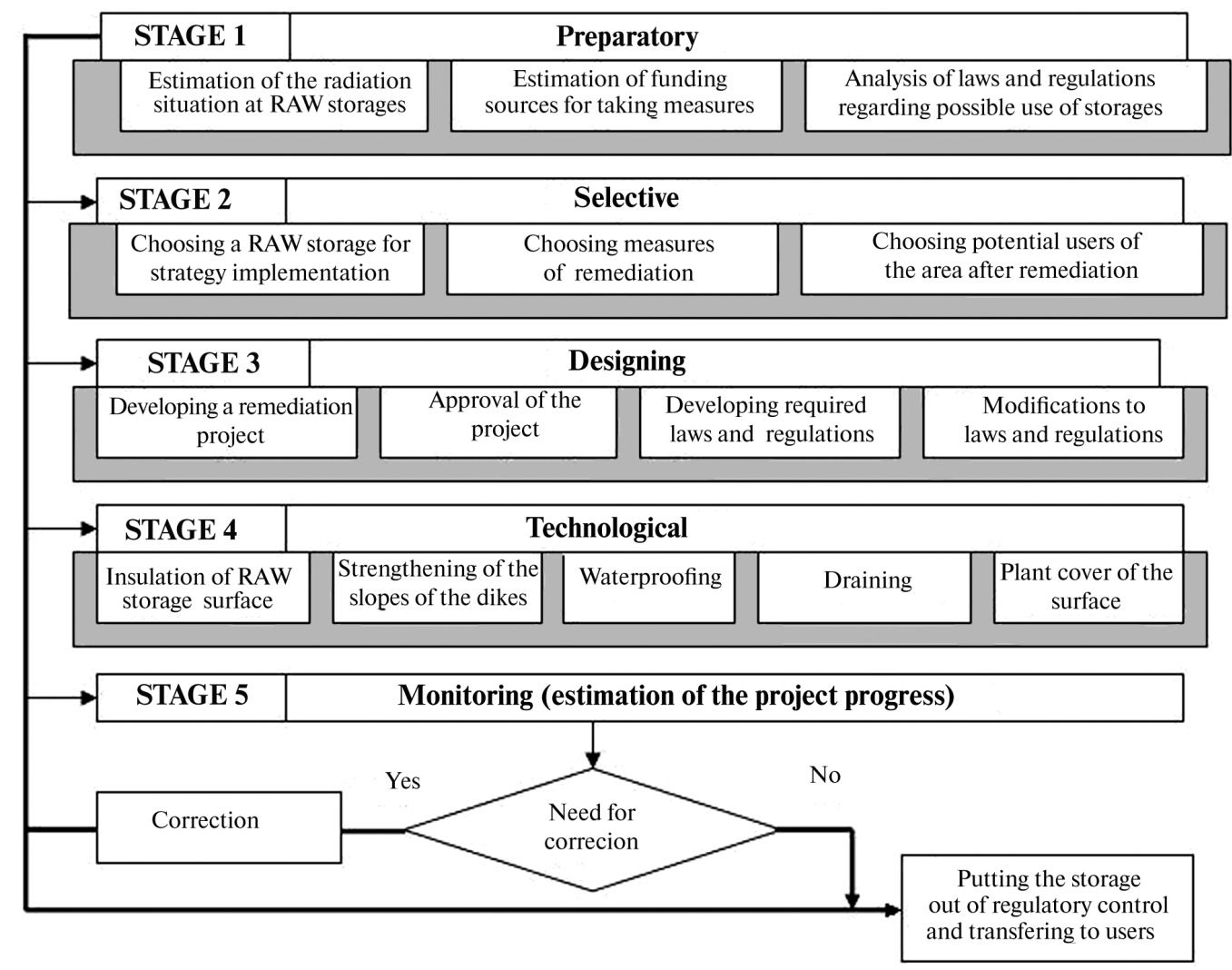

Fig. 2. The business mechanism of implementing the strategy of further management of uranium production wastes of the " $P C P$ " $P A$

quired, draft regulations and their approval or draft modifications to current laws and regulations concerning the issues of putting storage areas out of regulatory control and transferring them to new owners are implemented. If it is necessary, issues are agreed on granting permanent or temporary allowances to the new users of the territories to enhance their interest in using storage areas.

At the fourth level remediation works are conducted on the storage areas according to the developed project in order to put the storage areas out of regulatory control and transfer to the new users. In general, they include work for designing the storage surface, improving the ground coating, strengthening the slopes of the dike, waterproofing, draining, changing or improving the plant cover and others.

Administrative and civil control over implementation of the project (the fifth monitoring stage) is a mandatory stage while executing the chosen strategy as well as its timely correction according to the circumstances and conditions which can occur during the project implementation.

While choosing the direction of possible use of the areas of uranium production waste storage, it is necessary to consider all the objective and subjective factors which can influence final decision making and available technologies which can be applied within the programme of rehabilitative measures.

The conceptual approaches to choosing the directions of remediation of the tailings facility areas of uranium production of the "PCP" PA are given in Fig. 3.
Among the groups of factors in Fig. 3, we will first focus on those which are critical while choosing the recovery directions. One of the important factors, which influences the choice of further use of the storage area after taking remedial measures, is spacial location of storages in relation to the available industrial facilities and residential areas of Kamianske. Thus, storages "Zakhidne", "Tsentralnyi Yar", "Pivdenno-Skhidne" and "Dniprovske" are situated immediately on industrial lands and local communities are little interested in using these areas. A failed attempt to use the lands of the "Zakhidne" storage for locating private garages and storage facilities is an example of this. After the storage stopped being used in 1954, part of the tailings facilities was asphalted whereas in the south-western part of the disposal area, garages and warehouses were constructed. Eventually, the warehouses were demounted and the garages were relinquished and disassembled. The reasons for that are both poor consideration of the fact that radon accumulates in a great amount indoors (as a result of its exhalation from the surface of the storage) and inconvenience of using the garages situated far from the garage owners' places of residence and lack of possibility to use public transport to cover this distance.

Among medical and biological factors, those which define the radiation safety level for different cases of radiation exposure are important. Thus, while using the storage areas, the annual additional exposure dose (over the background dose for the given region) for the population should not exceed $1 \mathrm{mSv} /$ year, whereas for workers who will be involved in performing works at the stor- 


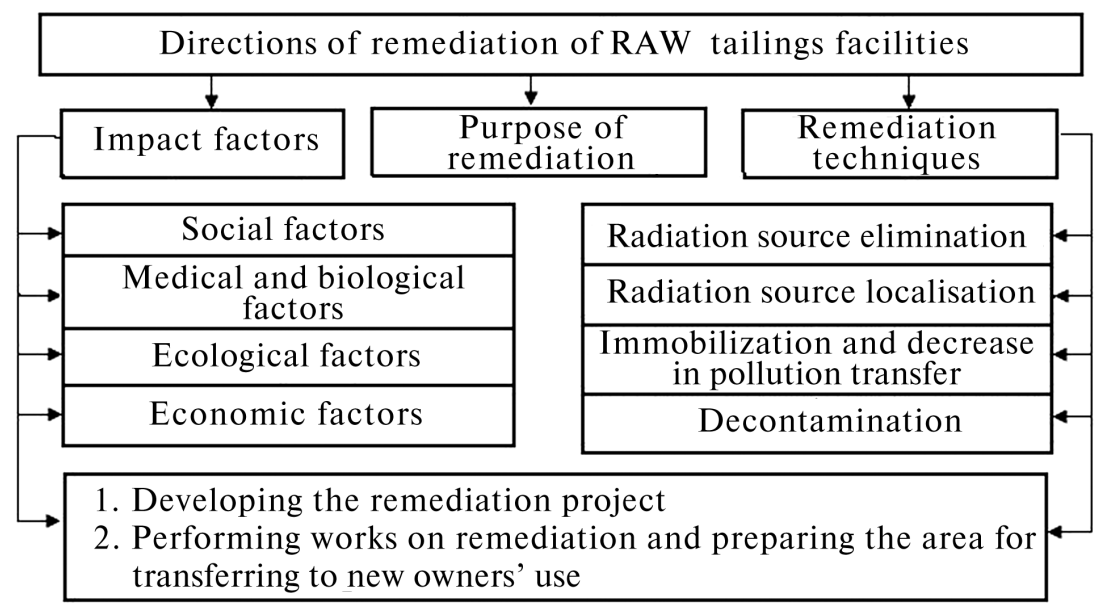

Fig. 3. The conceptual approaches to choosing the directions of remediation of the tailings facility areas of uranium production of the "PCP" $P A$

age site it should not be over $20 \mathrm{mSv} /$ year. While choosing the directions of possible use of the storage areas, it is necessary to consider the occurrence of radon accumulation in houses and buildings as a result of its exhalation from the surface of the storage, which restricts possible ways of using the storages. Moreover, construction of buildings required for future users of storage facilities should be conducted on the border territories with a low level of radon exhalation.

The ecological factors which influence the choice of possible application of the storage areas, first of all, are related to prevention of possible negative influence of the storages on the environment. Under normal conditions possible directions of using the storage areas should not lead to increasing radionuclide migration in underground waters and radionuclide advection as aerosols.

Among possible accident situations on the storage areas, fires are the most probable. That is why there should be specified restrictions for high trees whose root systems can reach disposed radioactive wastes, since soluble radionuclides accumulate in woody tissue and aerosolised they can lead to additional contamination of the environment in case of fire [7].

The social, medical and biological and ecological indicators are factors which mainly restrict possible directions of using the RAW storage areas. The main factor of making decisions on choosing certain measures within the remediation process is the economic one. According to the selected strategy of further management of RAW storages, the main principle of choosing remedial measures involves gaining as much benefit as possible from their implementation, i.e. the expenses on taking these measures after transferring the storage to a new user, are to be possibly rewarded within a short time.

Currently, the most widespread indicator which is used for estimating the investment efficiency is net present value (Net Present Value - NPV)

$$
N P V=-I N V+\sum_{1}^{T} \frac{C F_{k}}{(1+r)^{k}},
$$

where $I N V$ is the general volume of the investments by the project, in this particular case these are expenses on taking measures of remediation which allow putting storage areas out of regulatory control and transferring them to a new user; $C F_{k}$ is an annual money flow; $r$ is weighted mean cost of the capital; $k=1 \ldots T$ is the number of the current year of running the project.

In case when $\mathrm{y} N P V>0$ the investment project is considered profitable, if $N P V=0$, it proves the breakeven result of the project for an investor.

While estimating the efficiency of investment projects, the annual money flow in expression (1) is defined by the difference between all the benefits and costs of the project over a year

$$
C F_{k}=B_{k}-C_{k},
$$

where $B_{k}$ stands for benefits of the project over the $k^{\text {th }}$ year; $C_{k}$ stands for operating costs related to the project over the $k^{\text {th }}$ year.

In case of estimating the efficiency of investments into measures of remediation of the storage areas while defining the annual money flow, the benefits of the project over the $k^{\text {th }}$ year are replaced by the prevented damage of the society in general in the calculation over a year as a result of implementing certain measures; these are savings from putting the storages out of monitoring and control which are spent by the state on current activities directed at maintaining the storage areas in environmentally safe state, income taxes of the new users of the storage areas, land taxes paid by the new user and others.

The operating costs related to the project over the $k^{\text {th }}$ year can include the state's expenditures for external environmental control. In case of transferring functions of monitoring the storage state to the new user, these expenditures do not have to be considered while estimating the efficiency of the project.

In this case while taking measures at the $i^{\text {th }}$ storage, the expression (2) is presented as

$$
C F_{k i}=E_{i}^{p m}+E_{i}^{r m}+T_{i}+T_{l i},
$$

where $E_{i}^{p m}, E_{i}^{r m}$ are, correspondingly, expenditures for protecting and monitoring the state of the $i^{\text {th }}$ storage and the state's expenditures for taking current measures 
aimed at maintaining the storage areas in the environmentally safe state; $T_{i}, T_{l i}$ are, correspondingly, income taxes of the new users of the area of the $i^{\text {th }}$ storage and land taxes paid by the new user.

In this case annual money flow, which is defined in the calculation for every year of the project functioning, is a constant value and the expression (1) can be presented as

$$
N P V=-I N V+\sum_{1}^{T} \frac{E_{3}^{p m}+E_{3}^{r m}+T_{3}+T_{l^{3}}}{(1+r)^{k}} .
$$

Internationally, taking remediation measures at the waste storages to attract potential users of the storage areas legislatively includes full or partial (for a term of up to 10 years) immunity from income and land taxes [5]. In such cases it is sometimes possible to significantly decrease expenses on taking remediation measures which allow putting storage areas out of regulatory control, because the concerned user can do certain required work at their own expense. To decrease the expenditures for maintaining the uranium production storages and preventing their negative influence on the environment, in the area of their location projects on their use are developed aimed at the use of the storage surface for locating facilities of the social infrastructure and different kinds of industrial and business activities there, namely:

- creation of park belts;

- building recreation grounds;

- laying out leisure zones;

- construction of open storages;

- developing technical equipment stations;

- setting power facilities;

- locating other industrial facilities.

As a rule, after taking remediation measures and transferring the storage areas for locating facilities of the social infrastructure or industrial and business activities there, conducting earthwork operations is forbidden for a long time as well as construction of residential buildings, wells for drinking or agricultural purposes since they can cause loss of ground coating integrity on the storage site. Other issues to be strictly monitored include requirements for plant cover and drainage, unauthorized access of people to certain areas. When the facilities of the social infrastructure are located there, the local self-government authorities are responsible for meeting the safety requirements while using these areas, whereas the new owners are responsible for nature management safety when facilities of industrial and business activities are located on the lands transferred to nongovernment owners.

Moreover, it is worth emphasizing that evolution of the society in the future is closely related to extensive use of nuclear power [8]. Therefore, successful solution of the issues of storing uranium production wastes is becoming of utmost importance.

Coclusions. Based on the requirement for long-term maintenance of conformity of RAW storages state with laws and regulations in force and minimization of expenses on servicing the storages, the strategy of further management of uranium production wastes of the "PCP" PA has been developed which focuses on taking a number of remediation measures on contaminated territories which allow putting them out of service and regulatory control and getting these territories round to free, unrestricted or at least beneficial use by local communities or new owners.

The business mechanism of implementing the strategy of further management of uranium production wastes of the "PCP" PA has been suggested which consists of the following stages: preparatory, selective, designing, technological and monitoring.

Approaches to economic substantiation of directions of possible use of the storage areas with uranium production wastes have been suggested which aim at minimizing expenditures for servicing the storages.

\section{References.}

1. Lysychenko, H. V., Melnyk, Yu.P., Lysenko, T. V., Dudar, T. V. and Nikitina, N. B., 2010. Uranium ores of Ukraine: Geology, use, production wastes management. Kyiv: Naukova Dumka.

2. Voitsekhovych, O. V. and Makhoni, I. I., eds. 2014. Guidelines for involving the population in the programme of rehabilitation activities of the environment in the regions of uranium production legacy sites. Adapted and authorised report of IAEA work materials and the world experience. Kyiv: Interpres Ltd.

3. Sanzharova, N., Fesenko, S. and Reed, E., 2009. Processes governing radionuclide transfer to plants. In: Quantification of Radionuclide Transfer in Terrestrial and Freshwater Environments for Radiological Assessments. IAEA-TECDOC1616, IAEA, Vienna [online], pp. 123-138. Available at: <http://www.iaea.org/inis/collection/NCL CollectionStore/_Public/42/039/42039823.pdf?r=1> [Accessed 5 February 2017].

4. Falshtynskyi, V.S., Dychkovskyi, R. O., Saik, P. B., Lozynskyi, V.H. and Caceres E. Cabana, 2017. Formation of thermal fields by the energy-chemical complex of coal gasification. Naukovyi Visnyk Natsionalnoho Hirnychoho Universytetu, 5, pp. 36-42.

5. Howard, B. J., Beresford, N. A., Nisbet, A., Cox, G., Oughton, D. H., Hunt, J., Alvarey, B., Andersson, K. G., Liland, A. and Voigt, G., 2005. The STRATEGY project: decision tools to aid sustainable restoration and longterm management of contaminated agricultural ecosystems. Journal of Environmental Radioactivity, 83, pp. 275295. DOI: $10.1016 / j$.jenvrad. 2005.01.013.

6. Oughton, D., Forsberg, E. M., Bay, I., Kaiser, M. and Howard, B., 2004. An ethical dimension to sustainable restoration and long-term management of contaminated areas. Journal of Environmental Radioactivity, 74, pp. 171183. DOI: 10.1016/j.jenvrad. 2004.01.009.

7. Vandecasteele, C. M., Hardeman, F., Pauwels, O., Barnaerts, M., Carle, B. and Sombre, L., 2005. Attitude of a group of Belgian Stakeholders towards proposed agricultural countermeasures after a radioactive contamination: synthesis of the discussion within the Belgian EC-FARMING group. Journal of Environmental Radioactivity, 83, pp. 319-332. DOI: 10.1016/j.jenvrad. 2004.09.007.

8. Bazaluk, O., 2015. The Theory of Evolution. Philosophy and Cosmology, 15, pp. 25-33. 
Мета. Наукове обгрунтування стратегії подальшого поводження з відходами уранового виробництва Виробничого об'єднання „Придніпровський хімічний завод“ (ВО „ПХЗ“) та напрямів можливого використання території сховищ із відходами в майбутньому.

Методика. Результати отримані з використанням методів: критичного аналізу й систематизації- при оцінці впливу відходів уранового виробництва на населення й території; статистико-економічного аналізу - при дослідженні соціально-економічних і екологічних наслідків захоронення відходів уранового виробництва на урбанізованих територіях; економіко-математичного моделювання та оптимізації- при обгрунтуванні напрямів подальшого поводження 3 відходами уранового виробництва.

Результати. Оцінено вплив різних факторів на вибір стратегії подальшого поводження з відходами уранового виробництва ВО „ПХЗ““. Виходячи з вимоги довготривалого збереження відповідності стану сховищ радіоактивних відходів чинним нормативноправовим актам та мінімізації витрат на їх обслуговування, розроблена стратегія подальшого поводження з відходами уранового виробництва ВО „ПХЗ“. Дана стратегія зводитися до здійснення комплексу заходів з ремедіації на забруднених територіях, що дозволяють вивести їх з обслуговування й регулюючого контролю та повернути ці території до вільного, необмеженого або, принаймні, корисного використання місцевими громадами або новими власниками. Запропоновано організаційно-економічний механізм реалізації стратегії подальшого поводження зі сховищами відходів уранового виробництва ВО „ПХЗ“. Він включає підготовчий, вибірковий, проектний, технологічний і моніторинговий етапи та обгрунтування напрямів можливого використання даних територій у майбутньому, що спрямовані на мінімізацію витрат на обслуговування сховищ.

Наукова новизна. Запропоновані нові концептуальні підходи до стратегії подальшого поводження з відходами уранового виробництва ВО „ПХЗ“ й удосконалено організаційно-економічний механізм реалізації вибраної стратегії.

Практична значимість. Розроблено алгоритм процесу виведення територій сховищ із регулюючого контролю та, відповідно до принципу оптимізації, обгрунтовано порядок процесу планування й проведення заходів з ремедіації. Запропоновані найбільш доцільні варіанти використання територій сховищ відходів уранового виробництва ВО „ПХЗ“ після проведення заходів з їх ремедіації.

Ключові слова: економічне обгрунтування, стратегія, забруднення територій, відходи, уранове виробництво

Цель. Научное обоснование стратегии дальнейшего обращения с отходами уранового производства Производственного объединения „Приднепровский химический завод“ (ПО „ПХЗ“) и направле- ний возможного использования территории хранилищ с отходами в будущем.

Методика. Результаты получены с использованием методов критического анализа и систематизации - при оценке влияния отходов уранового производства на население и территории; статистико-экономического анализа при исследовании социально-экономических и экологических последствий захоронения отходов уранового производства на урбанизированных территориях; экономико-математического моделирования и оптимизации при обосновании направлений дальнейшего обращения с отходами уранового производства.

Результаты. Оценено влияние различных факторов на выбор стратегии дальнейшего обращения с отходами уранового производства ПО „ПХЗ““. Исходя из требований долговременного сохранения соответствия состояния хранилищ радиоактивных отходов действующим нормативно-правовым актам и минимизации расходов на их обслуживание разработана стратегия дальнейшего обращения с отходами уранового производства ПО „ПХЗ“. Данная стратегия сводиться к осуществлению комплекса мероприятий по ремедиации на загрязненных территориях, которые позволяют вывести их из обслуживания и регулирующего контроля и возвратить эти территории к свободному, неограниченному или, по крайней мере, полезному использованию местными общинами или новыми владельцами. Предложен организационно-экономический механизм реализации стратегии дальнейшего обращения с хранилищами отходов уранового производства ПО „ПХЗ““. Он включает подготовительный, выборочный, проектный, технологический и мониторинговый этапы и обоснование направлений возможного использования данных территорий в будущем, которые направлены на минимизацию расходов на обслуживание хранилищ.

Научная новизна. Предложены новые концептуальные подходы к стратегии дальнейшего обращения с отходами уранового производства ПО „ПХЗ“ и усовершенствован организационно-экономический механизм реализации выбранной стратегии.

Практическая значимость. Разработан алгоритм процесса вывода территорий хранилищ с регулирующего контроля и, согласно принципу оптимизации, обоснован порядок процесса планирования и проведения мероприятий по ремедиации. Предложены наиболее целесообразные варианты использования территорий хранилищ отходов уранового производства ПО „ПХЗ“ после проведения мероприятий по их ремедиации.

Ключевые слова: экономическое обоснование, стратегия, загрязнение территорий, отходы, урановое производство

Рекомендовано до публікації докт. екон. наук А.В. Бардасем. Дата надходження рукопису 02.12.16. 